\title{
ON THE TRANSFER OF VISIBLE RADIATION THROUGH SEA ICE AND SNOW
}

\author{
By Charles W. Thomas \\ (Museum of Comparative Zoölogy at Harvard College, Cambridge, Mass.)
}

\begin{abstract}
Coefficients of absorption of visible radiation are determined for sea ice and snow as a function of porosity of the medium and wave-length of energy refracted into it. A comparison is made between the values derived and those obtained by other investigators under similar snow conditions. A difference in results suggests a significant rôle of crystal size and orientation in the absorption properties of sea ice and snow.
\end{abstract}

RÉsumé. Les coefficients d'absorption du rayonnement visible sont déterminés pour la glace de mer et la neige en fonction de la porosité du milieu et de la longueur d'onde du rayonnement réfracté. Les valeurs obtenues sont comparées avec celles données par d'autres chercheurs pour des conditions de neige similaires. La différence des résultats conduit a suggérer que la grosseur des cristaux et leur orientation jouent un rôle important dans les proprietés d'absorption de la glace de mer et de la neige.

Zusammenfassung. Absorptionskoeffizienten der sichtbaren Strahlung werden für Meer-Eis und Schnee als Funktion der Porosität des Mediums und der Wellenlänge der in ihm refrangierten Energie dargestellt. Hieraus abgeleitete Werte werden mit solchen verglichen, die von anderen Forschern bei ähnlichen Schneeverhältnissen erhalten wurden. Die Verschiedenheit der Ergebnisse lässt einen beträchtlichen Einfluss der Grösse und der Orientierung der Kristalle auf die Absorptionseigenschaften von Meer-Eis und Schnee vermuten.

\section{INTRODUGTION}

Experiments leading to the collection of data herein were conducted in r 959 and r 960 on the sea ice of Drifting Station "Charley" in the Arctic Ocean; at the Arctic Research Laboratory, Point Barrow, Alaska and in the Cascade Mountains of Washington State.

Weston photoelectric cells, horizontally embedded, were used at all locations. On ice floe station "Charley" they were installed at the following depths: (I) ice surface, (2) $70 \mathrm{~cm}$. and (3) $350 \mathrm{~cm}$. The latter was just beneath the ice-water interface. Three cells were unfiltered and three (each) provided with red and yellow special-work filters. It was planned to use three blue filters in addition, but these were not available in special-work quality before the experiment began. To keep millivoltage within recorder-scale limits resistors were hooked in parallel in each circuit.

On the shore-fast ice at Point Barrow the cells were planted at the following places: (I) snow surface; (2) snow-ice interface; (3) $100 \mathrm{~cm}$. in the ice and (4) immediately above the ice-water interface, $180 \mathrm{~cm}$. beneath the ice surface. Because the study was carried out during a period of the year (May and June) when ice was deteriorating, intensity of light was measured manually to avoid risking the loss of a recorder.

For investigating the properties of snow as a medium of visible energy exchange, densities were measured and grain-size was estimated with a magnifying glass, as microscopic equipment was not available. In general, the technique of Liljequist (1956) was used in the collection of data from snow. Blue, green and red special-work filters were used and in some cases the polychromatic band was measured. Care was taken at each station to insure the homogeneous composition of the snow and that the incident intensity did not vary appreciably during the readings. Resistors were used on a switch to keep the millivoltmeter from "pegging".

\section{Discussion}

In computing the absorption of radiation in homogeneous ice and snow it is assumed that the Lambert law is valid. This may be written

$$
I_{z}=I_{\mathrm{o}} e^{-k z}
$$

where $I_{z}$ is the intensity of radiation at depth $z, I_{\mathrm{o}}$ is the non-reflected radiation available for transfer into the medium, and $k$ is the coefficient of absorption. 
To compute coefficients of absorption in a downward flux, the equation is solved for $-k$ and written

$$
-k=(\mathrm{r} / z) \ln \left(I_{z} / I_{o}\right)
$$

At Point Barrow albedo values were available, but at other places they were computed by determining $I_{\mathrm{o}}$ from (I) and (2) and deducing the albedo $A$ from the equation

where $I_{s}$ is the incident intensity.

$$
A=\mathrm{I}-\left(I_{\mathrm{o}} / I_{s}\right) \text {, }
$$

Porosity of snow and its permeability to air was investigated by Bader (1939) who related porosity $n$ to density by the equation

$$
n=\left(\gamma_{e}-\gamma_{s}\right) / \gamma_{e}
$$

\begin{tabular}{|c|c|c|c|c|c|c|c|}
\hline \multirow[b]{2}{*}{ Medium } & \multicolumn{6}{|c|}{ Porosity } & \multirow[b]{2}{*}{$\begin{array}{c}\text { Snow } \\
\text { condition }\end{array}$} \\
\hline & $\begin{array}{l}\text { Density } \\
\text { g.cm. }{ }^{-3}\end{array}$ & Porosily & $\begin{array}{l}\text { Wave-length } \\
\operatorname{m} \mu\end{array}$ & $\begin{array}{c}\text { Coefficient } \\
\text { of absorption, } k \\
\mathrm{~cm} .^{-1}\end{array}$ & $\begin{array}{c}\text { Albedo } \\
\text { per cent }\end{array}$ & $\begin{array}{c}\text { Solar } \\
\text { altitude }\end{array}$ & \\
\hline $\begin{array}{l}\text { Sea ice* } \\
\quad \text { (shore-fast) }\end{array}$ & 0.870 & 0.051 & polychromatic & 0.0219 & 65 & $24^{\circ} 09^{\prime}$ & \\
\hline $\begin{array}{l}\text { Sea ice* } \\
\quad \text { (pack) }\end{array}$ & $0 \cdot 900$ & 0.018 & $\begin{array}{c}\text { polychromatic } \\
59{ }^{\circ} \\
660\end{array}$ & $\begin{array}{l}0 \cdot 0 \begin{array}{lll}0 & 1 \\
0 \cdot 0084 \\
0 \cdot 0093\end{array} \\
0.0084\end{array}$ & $\begin{array}{l}66 \\
71 \\
94\end{array}$ & $09^{\circ} 27^{\prime}$ & \\
\hline Snow* & 0.285 & 0.689 & polychromatic & 0.275 & $8 I$ & $30^{\circ} 4^{8^{\prime}}$ & wet \\
\hline Snow* & $0 \cdot 3$ I 6 & 0.655 & polychromatic & $0 \cdot 243$ & 75 & $21^{\circ} 26^{\prime}$ & wet, corn \\
\hline Snow & 0.087 & 0.905 & $\begin{array}{c}\text { polychromatic } \\
420 \\
54{ }^{\circ} \\
66 \circ\end{array}$ & $\begin{array}{l}0.401 \\
0 \cdot 133 \\
0 \cdot 230 \\
0 \cdot 305\end{array}$ & $\begin{array}{l}73 \\
87 \\
88 \\
93\end{array}$ & $22^{\circ} 30^{\prime}$ & fresh \\
\hline Snow & $0 \cdot 348$ & 0.620 & $\begin{array}{l}\text { polychromatic } \\
420 \\
540 \\
660\end{array}$ & $\begin{array}{l}0 \cdot 246 \\
0 \cdot 185 \\
0 \cdot 198 \\
0 \cdot 231\end{array}$ & $\begin{array}{l}60 \\
71 \\
80 \\
83\end{array}$ & $34^{\circ} 18^{\prime}$ & wet, corn \\
\hline Snow & $0 \cdot 396$ & $0.5^{86}$ & polychromatic & 0.233 & 67 & $28^{\circ} 48^{\prime}$ & wet, fine \\
\hline Snow & $0 \cdot 428$ & 0.532 & $\begin{array}{l}420 \\
540 \\
660\end{array}$ & $\begin{array}{l}0 \cdot 163 \\
0 \cdot 205 \\
0 \cdot 231\end{array}$ & $\begin{array}{l}65 \\
72 \\
80\end{array}$ & $24^{\circ} 18^{\prime}$ & $\begin{array}{l}\text { moderate } \\
\text { grain-size }\end{array}$ \\
\hline Snow & $0 \cdot 439$ & $0.53 \mathrm{I}$ & $\begin{array}{l}420 \\
540 \\
660\end{array}$ & $\begin{array}{l}0 \cdot 193 \\
0 \cdot 200 \\
0 \cdot 231\end{array}$ & $\begin{array}{l}75 \\
8 \mathrm{I} \\
84\end{array}$ & $27^{\circ} 06^{\prime}$ & $\begin{array}{l}\text { moderate } \\
\text { grain-size }\end{array}$ \\
\hline Snow & $0 \cdot 500$ & $0.47 \mathrm{I}$ & $\begin{array}{l}420 \\
540 \\
660\end{array}$ & $\begin{array}{l}0 \cdot 095 \\
0 \cdot 136 \\
0 \cdot 145\end{array}$ & $\begin{array}{l}68 \\
86 \\
90\end{array}$ & $43^{\circ} \mathrm{o} 6^{\prime}$ & $\begin{array}{l}\text { moderate } \\
\text { grain-size }\end{array}$ \\
\hline Snow & $0 \cdot 620$ & $0 \cdot 34^{8}$ & $\begin{array}{l}\text { polychromatic } \\
420 \\
540 \\
660\end{array}$ & $\begin{array}{l}0 \cdot 196 \\
0 \cdot 096 \\
0 \cdot 117 \\
0 \cdot 144\end{array}$ & $\begin{array}{l}70 \\
74 \\
79 \\
83\end{array}$ & $38^{\circ} 46^{\prime}$ & corn \\
\hline Snow & 0.640 & $0 \cdot 302$ & $\begin{array}{c}\text { polychromatic } \\
420 \\
540 \\
660\end{array}$ & $\begin{array}{l}0.155 \\
0 \cdot 065 \\
0 \cdot 089 \\
0 \cdot 115\end{array}$ & $\begin{array}{l}75 \\
78 \\
78 \\
84\end{array}$ & $33^{\circ} \mathrm{I} 2^{\prime}$ & $\begin{array}{l}\text { wet, } \\
\text { moderate } \\
\text { grain-size }\end{array}$ \\
\hline Snow & $0 \cdot 720$ & 0.215 & $\begin{array}{c}\text { polychromatic } \\
420 \\
540 \\
660\end{array}$ & $\begin{array}{l}0.085 \\
0.056 \\
0 \cdot 066 \\
0.078\end{array}$ & $\begin{array}{l}70 \\
72 \\
83 \\
90\end{array}$ & $25^{\circ} 4^{2^{\prime}}$ & corn \\
\hline Snow & 0.810 & 0.117 & $\begin{array}{l}420 \\
540 \\
660\end{array}$ & $\begin{array}{l}0 \cdot 025 \\
0 \cdot 036 \\
0 \cdot 064\end{array}$ & $\begin{array}{l}70 \\
80 \\
84\end{array}$ & $46^{\circ} \mathrm{I} 6^{\prime}$ & $\begin{array}{l}\text { corn, } \\
\text { large } \\
\text { grain-size }\end{array}$ \\
\hline
\end{tabular}

where $\gamma_{e}$ is the density of ice $\left(0.9 \mathrm{I} 7 \mathrm{~g} . \mathrm{cm}^{-3}\right)$, and $\gamma_{s}$ is the density of snow.

Table I. Coefficients of Absorption and Albedo of Sea Ice and Snow as a Function of Density and

\footnotetext{
* Values averaged over a period of time.
} 
The results of the investigation of the transfer of visible radiation in sea ice and snow are shown in Table I. Because concentration of sediments in shore-fast ice at Point Barrow is high, the coefficient of absorption is nearly double that of pack ice in the central Arctic Ocean.

Table II compares some data in Table I with representative observations of other authors, among whom it shows a lack of accord. Moreover, Liljequist (1956) observed a marked selective extinction of light while Sauberer (1938) remarked that the extinction of different colors within the band from $0.38 \mu$ to $0.78 \mu$ is, in the main, the same. Some minor variation in results of measurements in common media is to be expected due to multiple light reflection at depth and instrumentation factors. However, the magnitude of disagreement in Table II makes it apparent that absorption of light cannot be solely a function of wave-length and the porosity, density, grain-size or humidity of the medium. Discounting such foreign elements as brine pockets, interstices and inclusions, orientation of the $c$-axes of ice crystals (which are ordinarily uniaxial) must significantly affect transparency of a medium for refracted light. This may well account for incongruities in the value of $-k$ for common media. In fresh snow the shape of the crystals, and in old snow that of the grains, surely also influences transparency.

Table II. Values of Coefficients of Absorption as determined by Various Authors for Visible Radiation in Certain Types of Snow

Authors
Kalitin (1931)
Eckel and Thams (1939)
Liljequist (1956)
Kudō (1941)
Table I
Devaux (1933)
Thams (1938)
Sauberer (1938)
Table I
Liljequist (1956)
Liljequist (1956)
Liljequist ( 1956$)$
Liljequist (1956)
Table I
Table I
Table I

Wave-length
m $\mu$
polychromatic
polychromatic
polychromatic
polychromatic
polychromatic
polychromatic
polychromatic
polychromatic
polychromatic
420
520
590
650
420
540
660

\section{Type of snow}

wet

wet

wet

wet

wet

fresh

fresh

fresh

fresh

standard*

standard*

standard*

standard*

standard*

standard* standard*

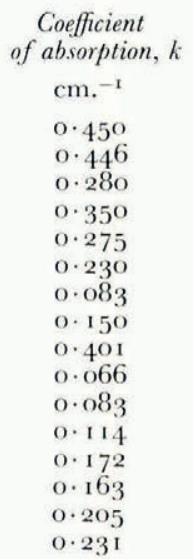

* Standard snow, according to Liljequist ( $195^{6}$ ), has a density of 0.42 to 0.43 g.cm. ${ }^{-3}$ and a grain-size of $0.3 \mathrm{~mm}$.

For example, dendritic, plate, cup and needle crystal types should have different optical properties even though the density and porosity be identical. Furthermore, in fresh snow, crystals - particularly dendritic ones - may become unevenly rimed. In old snow, the formation of depth-hoar layers can also vary the absorption of energy.

\section{Conclusions}

The above hypothesis suggests a need for investigation of absorption properties of ice and snow as a function of crystal size and orientation.

Notwithstanding the incongruity of results shown in Table II, the conclusions of other investigators support the data presented in Table I in making apparent the following fact: Absorption coefficients and albedos vary inversely with density of the medium and frequency of the energy.

When sufficient data are collected and tabulated it will be possible to determine by inspection, any one of the several variables governing the transfer of visible radiation. For example, with space as a variable, the size and shape of a medium may be delimited. In areas of pack ice where surface observations are available, thickness and perhaps other characteristics may be inferred by a submarine on a traverse beneath the ice-water interface. Or 
the ice seaman (who is concerned with crystal orientation) may improve his breaking and navigating techniques.

\section{Acknowledgement}

The help of Robert Ditzler, Daniel Hale and Richard Summerfeld in the collection of data presented herein is gratefully acknowledged.

MS. received 7 August 1962

\section{REFERENCES}

Bader, H. 1939. Mineralogische und strukturelle Charakterisierung des Schnees und seiner Metamorphose. Beiträge zur Geologie der Schweiz. Geotechnische Serie. Hydrologie, Lief. 3, p. I-61.

Devaux, J. 1933. L'économie radiothermique des champs de neige et des glaciers. Annales de Physique, Tom. 20, juillet-août, p. 5-67.

Eckel, O., and Thams, C. 1939. Untersuchungen über Dichte-, Temperatur- und Strahlungsverhältnisse der Schneedecke in Davos. Beiträge zur Geologie der Schweiz. Geolechnische Serie. Hydrologie, Lief. 3, p. 273-340.

Kalitin, N. N. 193. Die Strahlungscigenschaften der Schneedecke. Gerlands Beiträge zur Geophysik, Bd. 34, p. $354-66$.

Kudō, K. 1941. Sekisetsu-chū no akarusa [Brightness within the snow cover]. Seppyō, Vol. 3, p. 390-95.

Liljequist, G. H. 1956. Energy exchange of an Antarctic snow-field. Short-wave radiation (Maudheim, $71^{\circ} \mathrm{og}^{\prime} \mathrm{S}$, $\left.{ }_{10}^{\circ} 56^{\prime} \mathrm{W}\right)$. Norwegian-British-Swedish Antarctic Expedition, 1949-52. Scientific Results (Oslo, Norsk Polarinstitutt), Vol. 2, Pt. 1A, p. 1-109.

Sauberer, F. 1938. Versuche über spektrale Messungen der Strahlungseigenschaften von Schnee und Eis mit Photoelementen. Meteorologische Zeitschrift, Bd. 55, Ht. 7, p. 250-55.

Thams, C. 1938. Über die Strahlungseigenschaften der Schneedecke. Gerlands Beiträge zur Geophysik, Bd. 53, p. $37^{1-88}$. 